AGRITECH, Vol. 37, No. 2, Mei 2017, Hal. 115-120

DOI: http://doi.org/10.22146/agritech.25324

ISSN 0216-0455 (Print), ISSN 2527-3825 (Online)

Tersedia online di https://jurnal.ugm.ac.id/agritech/

\title{
Aplikasi Antioksidan dari Ekstrak Lamun (Cymodocea rotundata) pada Minyak Ikan Tongkol (Euthynnus affinis)
}

\author{
Application Antioxidant from Seagrass (Cymodocea rotundata) Extract in Swordfish (Euthynnus affinis) Oil \\ Amalia Rahmi Puspasari, Eko Nurcahya Dewi, Laras Rianingsih
}

\author{
Jurusan Perikanan, Fakultas Perikanan dan Ilmu Kelautan, Universitas Diponegoro, \\ Jl. Prof. Soedarto, S.H., Semarang 50000, Indonesia \\ Email: laras_rianingsih@yahoo.com
}

Submisi: 2 Desember 2015; Penerimaan: 9 Agustus 2016

\begin{abstract}
ABSTRAK
Cymodocea rotundata adalah spesies lamun yang mengandung senyawa flavonoid dan fenolik sehingga diharapkan mampu mencegah terjadinya oksidasi lemak melalui penghambatan pembentukan radikal bebas. Penelitian ini bertujuan mengetahui efek konsentrasi ekstrak lamun yang berbeda terhadap nilai free fatty acid (FFA), peroxide value (PV), dan thiobarbituric acid (TBA) selama penyimpanan suhu ruang. Materi yang dipergunakan adalah ikan tongkol dengan kisaran panjang $40 \pm 1 \mathrm{~cm}$ dan berat sekitar $1 \mathrm{~kg} /$ ekor yang diolah menjadi minyak ikan. Rancangan percobaan yang digunakan adalah Rancangan Acak Lengkap (RAL) pola faktorial untuk mengetahui pengaruh konsentrasi ekstrak lamun $(0 \% ; 0,1 \% ; 0,2 \%$; dan $0,3 \%)$ dan lama penyimpanan (hari ke-0 dan hari ke-5) pada suhu ruang terhadap kualitas minyak ikan. Hasil penelitian menunjukkan nilai FFA berkisar antara 0-27,477\%, nilai PV berkisar antara 0-46,737 $\mathrm{mEq} / \mathrm{kg}$, dan nilai TBA berkisar antara 3,310-8,731 malonaldehid. Studi ini menunjukkan interaksi antara konsentrasi ekstrak lamun dan waktu penyimpanan sangat berpengaruh $(p<0,05)$ terhadap nilai FFA, PV, dan TBA.
\end{abstract}

Kata kunci: Antioksidan; Cymodocea rotundata; penyimpanan suhu ruang; lamun; minyak ikan

\begin{abstract}
Cymodocea rotundata is a seagrass, has a potential antioxidant capacity due to have flavonoid and phenolic compounds that could prevent free radicals. This research aimed was to determine the effect of different concentrations of seagrass extracts on the value of free fatty acids (FFA), peroxide value (PV), and thiobarbituric acid (TBA) during storage at room temperature. The material used in this study was swordfish which were processed into fish oil. The research was conduct through laboratory experiments using a completely randomized design (CRD) which to evaluate the effect of seagrass extract concentrations $(0 \%, 0.1 \%, 0.2 \%$, and $0.3 \%)$ and storage time (days 0 and 5 ) on the oil quality. The results showed FFA values ranged from 0 to $27.477 \%$, PV value between 0 to $46.737 \mathrm{mEq} / \mathrm{kg}$, and TBA values ranged from 3.310 to 8.731 malonaldehyde. Based on the results of the study showed that the interaction between seagrass $C$. rotundata extract concentration and storage time was significantly $(p<0.05)$ influence the value of FFA, PV, and TBA.
\end{abstract}

Keywords: Antioxidants; Cymodocea rotundata; room storage; seagrass; swordfish oil 


\section{PENDAHULUAN}

Kerusakan lemak yaitu oksidasi dapat dihambat menggunakan berbagai macam senyawa antioksidan. Aktivitas antioksidan sintetik biasanya sangat kuat. Jacoeb dkk. (2011) melaporkan hasil penelitiannya bahwa BHA dan BHT yang merupakan antioksidan sintetik berpotensi karsinogenik. Antioksidan merupakan senyawa yang dapat menghambat atau mencegah oksidasi lemak, asam nukleat dan lain-lain dengan menghambat terjadinya tahapan oksidasi (inisiasi atau propagasi). Kegunaan antioksidan yang lain yaitu memperpanjang umur simpan dengan melindungi pangan dari proses kemunduran kualitas yang disebabkan oleh oksidasi seperti ketengikan. Hal tersebut juga diungkapkan oleh Winarsi (2007), bahwa antioksidan adalah inhibitor yang dapat menghentikan reaksi oksidasi dengan mencegah terjadinya radikal atau dengan menetralisir radikal bebas.

Lamun mengandung bahan pangan seperti protein, lemak, serat pangan serta senyawa metabolit sekunder flavonoid, hidroquinon, steroid dan triterpenoid. Beberapa lamun telah diteliti kemampuan antioksidannya, misalnyajenis Enhalus acoroides oleh Kannan dkk. (2010), jenis Posidonia oceanic oleh Kesroui dkk. (2011) dan Chiara dkk. (2015).

Asam lemak bebas yang terkandung dalam minyak ikan sangat bervariasi baik jumlah atom C-nya (12-26) ataupun jumlah ikatan rangkapnya (0-6). Asam lemak jenuh pada ikan sebanyak $15-25 \%$, asam lemak tidak jenuh berikatan tunggal sebanyak $35-60 \%$ dan asam lemak tidak jenuh berikatan ganda sebanyak $25-40 \%$ yang telah terbukti berefek baik bagi kesehatan misalnya penyakit jantung, kanker, artritis dan lainlain. Minyak ikan adalah bahan yang memiliki kandungan asam lemak tak jenuh yang tinggi (Berge dan Barnathan, 2005).

\section{METODE PENELITIAN}

\section{Preparasi Sampel}

Pengambilan lamun C. rotundata dilakukan di Pantai Sepanjang, Yogyakarta. Sampel segera dicuci menggunakan air laut, dibilas dengan air tawar, dikemas menggunakan plastic dan disimpan menggunakan box pendingin.

\section{Ekstraksi Lamun}

Proses ekstraksi lamun dilakukan menurut prosedur Malangngi dkk. (2012). Sampel lamun, dikeringkan sampai kadar air menyusut sekitar 95\%. Setelah kering, lamun diblender sehingga menjadi bubuk dengan tujuan agar memudahkan pada saat ekstraksi. Bubuk lamun yang sudah kering ditimbang sebanyak $20 \mathrm{~g}$ dan direndam ke dalam 100 $\mathrm{mL}$ pelarut metanol $96 \%$ selama 24 jam. Suspensi ekstrak lamun disaring dengan menggunakan kertas saring dan dimaserasi selama $3 \times 24$ jam. Hasil maserasi ekstrak lamun dalam bentuk pasta dikeringkan dengan rotary evaporator pada suhu $40{ }^{\circ} \mathrm{C}$.

\section{Uji Fitokimia}

Prosedur analisis secara kuantitatif senyawa flavonoid dilakukan menurut Soebagio dkk. (2007) sebagai berikut: ekstrak lamun dalam bentuk pasta dipanaskan menggunakan waterbath, ditambahkan alkohol, dihomogenkan dengan cara dikocok-kocok. Tertariknya warna kuning-merah di alkohol menunjukkan positif flavonoid.

\section{Uji DPPH (1,1 difenil-2-pikrilhidrazil)}

Pengujian DPPH menggunakan metode Bloish (Khotimah dkk., 2013) dengan menggunakan lima variabel konsentrasi yaitu 0 ppm (blanko), 25 ppm, 50 ppm, 100 ppm, dan 200 ppm. Data absorbansi diperoleh dari berbagai konsentrasi yang dilakukan. Untuk mengetahui besarnya nilai $\mathrm{IC}_{50}$ dari sampel maka sebelumnya dilakukan perhitungan \% inhibisi dengan rumus:

$\%$ penangkapan radikal $=\frac{(1-\text { absorbansi larutan uji })}{\text { absorbansi kontrol }} 100 \%$

Setelah data \% inhibisi atau \% penangkapan radikal didapatkan, maka berikutnya dilakukan perhitungan untuk mendapatkan nilai $\mathrm{IC}_{50}$, yaitu bilangan yang menyatakan aktivitas radikal bebas. Reduksi aktivitas DPPH menjadi 50\%nya disebabkan oleh larutan sampel yang ditambahkan. Besar IC50 diperoleh dari perhitungan persentase penghambatan atau \% inhibisi larutan ekstrak menggunakan menggunakan persamaan yang diperoleh dari kurva regresi linier.

\section{Prosedur Pembuatan Minyak Ikan Wet Rendering}

Ikan tongkol segar dengan panjang berkisar $40 \pm 1$ $\mathrm{cm}$ dipotong keci-kecil menjadi bentuk dadu dengan berat lebih kurang $100 \mathrm{~g}$ (memerlukan sekitar 3 ekor). Minyak ikan diperoleh dengan cara: sampel ikan dimasukkan wadah stainless steel kemudian diberi akuades sebanyak $500 \mathrm{~mL}$. Perebusan ikan dilakukan sampai mendidih selama 30 menit, setelah itu didiamkan serta diaduk perlahan selama 30 menit. Selanjutnya sampel rebusan disaring. Minyak kasar hasil penyaringan dimurnikan dengan cara ditambahkan $\mathrm{NaCl}$ 2,5\%, dipanaskan $50{ }^{\circ} \mathrm{C}$, dipisahkan bagian minyak dan air menggunakan corong pisah. Bagian minyak diberikan bentonit serta diaduk. Setelah dibiarkan sebentar, minyak disaring. Hasil penyaringan adalah minyak yang jernih kemudian disimpan dalam tempat yang tertutup rapat dan gelap (Panagan, 2012). 


\section{Uji FFA (Free Fatty Acid)}

Prosedur uji FFA (free fatty acid) dilakukan menurut prosedur Farvin dkk. (2012) menambahkan ekstrak lamun yang berbentuk bentuk pasta sebanyak $10 \mathrm{~g}$ dengan 15 $\mathrm{ml}$ etanol kemudian dititrasi dengan $0,1 \mathrm{M} \mathrm{NaOH}$. PP (phenolphthalein) ditambahkan sebanyak 5 tetes sebagai indikator. FFA dihitung dalam \% asam oleat. BM asam oleat yaitu sebesar 256 .

$\% F F A=\frac{\text { BM asam oleat } \mathrm{x} \mathrm{ml} \mathrm{NaOH}}{\text { berat sampel }} 100 \%$

\section{Uji PV (Peroxide Value)}

Prosedur dalam uji PV (peroxide value) dilakukan menurut Aminah (2010) yaitu sebanyak $5 \mathrm{~mL}$ minyak ikan dimasukkan ke dalam erlenmeyer ukuran $250 \mathrm{~mL}$, kemudian $30 \mathrm{~mL}$ ditambahkan larutan asam asetat glacial dan kloroform (3:2). Setelah minyak larut, ditambahkan $0,5 \mathrm{~mL}$ larutan jenuh $\mathrm{KI}$ dengan erlenmeyer dalam keadaan tertutup, didiamkan selama 1 menit sambil digoyang kemudian diencerkan dengan aquades sebanyak $30 \mathrm{~mL}$. Larutan dititrasi dengan $\mathrm{Na} 2 \mathrm{~S} 2 \mathrm{O} 3$ $0,01 \mathrm{~N}$. titrasi dihentikan pada saat hampir hilangnya warna kuning larutan kemudian dimasukkan $0,5 \mathrm{ml} 1 \%$ amilum dan dititrasi kembali sampai mulai menghilangnya warna biru. Peroside value adalah miliequivalen peroksida pada $1000 \mathrm{~g}$ sampel dan dihitung dengan rumus:

Angka peroksida $=\frac{\mathrm{mL} \mathrm{Na}_{2} \mathrm{~S}_{2} \mathrm{O}_{3} \times \mathrm{N} \mathrm{Na}_{2} \mathrm{~S}_{2} \mathrm{O}_{3} \times 1000}{\text { berat sampel }(g)}$

Keterangan:

mL Na $\mathrm{S}_{2} \mathrm{O}_{3}$ : volume titran

$\mathrm{N} \mathrm{Na}_{2} \mathrm{~S}_{2} \mathrm{O}_{3}$ : normalitas $\mathrm{Na}_{2} \mathrm{~S}_{2} \mathrm{O}_{3}(0,01 \mathrm{~N})$

\section{Uji TBA (Thiobaturic Acid)}

Uji TBA menurut prosedur Yanti dan Rochima (2009): sampel minyak ikan ditimbang $10 \mathrm{~g}$ dan ditambah $50 \mathrm{~mL}$ akuades, kemudian diblender selama 60 detik, dimasukkan dalam labu destilasi bersama 47,5 akuades. Nilai $\mathrm{pH}$ diatur menjadi 1,5 dengan cara menambahkan $\mathrm{HCl} 5 \mathrm{~mL}$, batu didih, dan pencegah buih secukupnya. Sebanyak $5 \mathrm{~mL}$ destilat yang diperoleh diaduk secara merata kemudian dimasukkan ke tabung reaksi bertutup. Sebanyak $5 \mathrm{~mL}$ reagen TBA dimasukkan dan dipanaskan selama 35 menit dalam air mendidih. Langkah terakhir tabung didinginkan dengan air selama 10 menit kemudian ditera absorbansinya $(\lambda 528 \mathrm{~nm}$, blanko sebagai titik nol). $5 \mathrm{~mL}$ akuades dan $5 \mathrm{~mL}$ reagen TBA yang diperlakukan seperti sampel digunakan sebagai blanko. Nilai TBA adalah mg malonaldehid per $1000 \mathrm{~g}$ sampel dan dihitung dengan rumus:

$$
\text { Nilai } T B A=\frac{7,8 \times \mathrm{D} \times 3}{\text { berat sampel }(\text { malonaldehi } / \mathrm{kg})}
$$

Keterangan:

D: absorbansi

\section{Analisis Data}

Rancangan percobaan menggunakan Rancangan Acak Lengkap (RAL) pola faktorial. Perlakuan ada 2 faktor yaitu konsentrasi ekstrak lamun $(0 \% ; 0,1 \% ; 0,2 \%$; dan $0,3 \%)$ dan lama penyimpanan (hari ke-0 dan hari ke-5) pada suhu ruang. Data penelitian yang didapat dianalisis dengan ANOVA. Apabila ada data perlakuan yang berbeda nyata pengaruhnya terhadap respon, maka dilakukan uji lanjut Beda Nyata Jujur (BNJ) untuk mengetahui perbedaan antar perlakuannya.

\section{HASIL DAN PEMBAHASAN}

\section{Uji Fitokimia}

Data uji kandungan senyawa bioaktif pada ekstrak lamun C. rotundata disajikan pada Tabel 1. Hasil uji fitokimia metabolit sekunder dalam kandungan senyawa bioaktif pada ekstrak lamun C. rotundata yaitu terbukti adanya flavonoid dan Fenolik. Senyawa flavonoid dan fenolik diketahui dapat menangkal radikal bebas. Menurut Winarsi (2007) senyawa flavonoid memiliki aktivitas antioksidan yang kuat pada system biologis yaitu mampu menghambat penggumpakan sel darah. Selain itu Bougatef dkk. (2010) melaporkan bahwa vitamin $\mathrm{C}, \alpha$-tokoferol dan senyawa fenolik yang terdapat secara alami pada berbagai sayuran, buah dan tumbuhan memiliki kemampuan untuk mengurangi kerusakan oksidatif.

\section{Uji DPPH}

Hasil uji menunjukkan bahwa ekstrak lamun $C$. rotundata menghasilkan senyawa antioksidan sebesar 42,5 ppm. Menurut Ulfa dkk. (2014), suatu senyawa dinilai memiliki aktivitas antioksidan yang sangat kuat bila nilai IC50 lebih kecil dari 50 ppm, kuat bila IC50 50-100 ppm, sedang bila IC50 100-150 ppm, dan lemah bila IC50 151-200 ppm.

\section{Uji FFA}

Penyimpanan hari ke-0 pada Tabel 2 menyatakan bahwa produk yang ditambahkan antioksidan ekstrak lamun $0,1 \%$, $0,2 \%$, dan $0,3 \%$ memiliki nilai FFA yang berbeda nyata ( $p$ $<0,05)$ dengan produk yang tidak mengalami penambahan antioksidan, hal yang sama ditunjukkan pula pada

Tabel 1. Hasil uji kandungan senyawa bioaktif ekstrak lamun C. rotundata

\begin{tabular}{ccc}
\hline Komponen & Jumlah $(\%)$ & Keterangan \\
\hline Flavonoid & 89 & $(+)$ \\
Fenolik & 45 & $(+)$ \\
\hline Keterangan: Tanda $(+)$ menandakan adanya senyawa bioaktif
\end{tabular}


penyimpanan hari ke-5. Setelah mengalami penyimpanan pada suhu ruang selama 5 hari kerusakan lemak mulai terjadi yang ditandai dengan adanya peningkatan jumlah FFA sebesar 8,53\%. Sedangkan FFA yang dengan ditambahkan antioksidan pada konsentrasi $0,1 \%$ naik sebesar $27,14 \%$ dan konsentrasi $0,2 \%$ naik menjadi $27,48 \%$, namun pada konsentrasi $0,3 \%$ turun sebesar 8,79\%. Hasil penelitian yang sama ditunjukkan oleh penelitian Prabowo dkk. (2013), yang menyatakan bahwa terdapat peningkatan FFA pada sampel sistem emulsi minyak ikan mulai awal penyimpanan sampai penyimpanan 38 hari walaupun dengan penambahan ekstrak antioksidan dariSargassum sp. Hal inimengindikasikan bahwa minyak ikan telah mengalami oksidasi dan sudah mengalami reaksi lanjutan atau sudah terurai menjadi senyawa yang lain. Perbedaan nilai penambahan FFA juga disebabkan oleh asam lemak yang terkandung pada ikan tongkol. Semakin banyak ikatan rangkapnya maka laju oksidasi minyak ikan lebih cepat. Ariyani dkk. (2012), menyatakan kandungan asam lemak berantai panjang dengan banyak ikatan rangkap menjadi pemicu terjadinya oksidasi lemak. Komponen PUFA yang cukup tinggi pada lemak ikan sangat sensitif terhadap kerusakan yang disebabkan proses oksidasi.

\section{Uji PV}

Hasil pengujian FFA pada minyak ikan tongkol dengan perbedaan konsentrasi ekstrak lamun $C$. rotundata diperlihatkan pada Tabel 3. Tabel tersebut menunjukkan bahwa pada penyimpanan hari ke-0, produk yang ditambah ekstrak lamun yaitu perlakuan A1, A2 dan A3 memiliki nilai PB berbeda nyata $(p<0,05)$ dengan produk yang tidak ditambah antioksidan. Pada hari ke-5 PV mengalami kenaikan sebesar $12,352 \mathrm{mEq} / \mathrm{kg}$, sedangkan sampel yang ditambahkan antioksidan pada konsentrasi 0,1\%, kandungan PV naik sebesar 22,033 $\mathrm{mEq} / \mathrm{kg}$ dan konsentrasi $0,2 \%$ naik menjadi $35,386 \mathrm{mEq} / \mathrm{kg}$. Namun pada penambahanan

Tabel 2. Hasil pengujian FFA (\%) pada minyak ikan tongkol dengan perbedaan konsentrasi ekstrak lamun $C$. rotundata

\begin{tabular}{ccrcr}
\hline \multirow{2}{*}{$\begin{array}{c}\text { Lama } \\
\text { penyimpanan } \\
\text { (hari) }\end{array}$} & A0 & A1 & A2 & A3 \\
\cline { 2 - 5 } & & & & \\
\hline T0 & $0,08 \pm 0,03^{\mathrm{a}}$ & $2,781 \pm 0,17^{\mathrm{b}}$ & $24,25 \pm 0,95^{\mathrm{d}}$ & $25,08 \pm 0,24^{\mathrm{d}}$ \\
T5 & $8,53 \pm 0,39^{\mathrm{c}}$ & $27,136 \pm 0,26^{\mathrm{e}}$ & $27,48 \pm 1,65^{\mathrm{e}}$ & $8,79 \pm 0,15^{\mathrm{c}}$ \\
\hline Keterangan: & & &
\end{tabular}

Data merupakan hasil rata-rata dari tiga kali ulangan \pm standar deviasi.

Data yang diikuti dengan superscript yang berbeda menunjukkan perbedaan yang nyata $(p<5 \%)$

A0 : Tanpa penambahan ekstrak lamun (kontrol)

A1 : Penambahan ekstrak lamun dengan konsentrasi $0,1 \%$

A2 : Penambahan ekstrak lamun dengan konsentrasi $0,2 \%$

A3 : Penambahan ekstrak lamun dengan konsentrasi $0,3 \%$

T0 : Lama penyimpanan pada hari ke-0

T5 : Lama penyimpanan pada hari ke-5 konsentrasi ekstrak lamun nilai PV turun $0,3 \%$ atau sebesar $29,711 \mathrm{mEq} / \mathrm{kg}$. Hal ini mengindikasikan bahwa minyak ikan telah mengalami oksidasi dan sudah mengalami reaksi lanjutan atau sudah terurai menjadi senyawa yang lain. Perbedaan nilai peningkatan juga disebabkan oleh kondisi pada saat preparasi dan penyimpanan pada suhu ruang. Hasil ini sesuai dengan penelitian Ariyani dkk. (2012), yang menunjukkan bahwa penyimpanan pada suhu kamar $(26,5$ sampai $28,5^{\circ} \mathrm{C}$ ) yang relatif lama diduga juga berkontribusi terhadap penurunan PUFA pada minyak ikan.

Penyebab lain kerusakan minyak ikan yaitu karena adanya zat warna pada lamun $C$. rotundata. Zat warna yang ikut terekstrak dalam minyak ikan pada saat ekstraksi dapat mengindikasikan semakin meningkatnya oksidasi. Pada lamun $C$. rotundata terdapat klorofil $\alpha$ dan $\beta$. Hal tersebut sesuai hasil penelitian Pradheebha dkk. (2011) yaitu klorofil $\alpha$ dan $\beta$ pada $C$. rotundata mempunyai nilai berkisar 0,02-0,19 mg/g dan 0,03-0,149 mg/g. Penelitian ini tidak melakukan pengukuran klorofil. Penelitian kali ini melakukan pengukuran nilai PV. Berdasarkan nilai PV yang diperoleh bisa disimpulkan yaitu nilai PV naik seiring naiknya konsentrasi ekstrak lamun yang mengindikasikan tingkat oksidasi yang juga semakin tinggi. Sedangkan hasil pengukuran fitokimia diperoleh data bahwa ekstrak lamun mengandung senyawa flavonoid dan fenolik yang menurut pustaka acuan (Winarsi, 2007; Bougatef dkk., 2010) memiliki kemampuan mengurangi kerusakan oksidatif. Jadi hal ini kontradiktif atau tidak sejalan dengan teori bahwa semakin tinggi konsentrasi lamun yang ditambahkan pada perlakuan penelitian kali ini (minyak ikan) yang berarti semakin tinggi pula jumlah/konsentrasi flavonoid dan fenoliknya justru menghasilkan tingkat kerusakan oksidatif yang semakin tinggi yang ditunjukkan dengan kenaikan PV. Berdasarkan fenomena ini diduga ada senyawa prooksidan dalam lamun.

Menurut pustaka Pradheebha dkk. (2011), lamun memiliki kandungan klorofil yang dapat bersifat sebagai prooksidan. Jadi semakin tinggi perlakukan penambahan konsentrasi ekstrak lamun akan terdapat kenaikan konsentrasi antioksidan (flavonoid dan fenolik) tetapi juga terjadi kenaikan prooksidan (klorofil) yang pada hasil akhir penelitian ini terjadi kenaikan PV dengan semakin tingginya kenaikan ekstrak lamun. Jadi diduga prooksidan ekstrak lamun yang ada lebih kuat pengaruhnya daripada antioksidan pada ekstrak lamun.

\section{Uji TBA}

Berdasarkan Tabel 4, pada masa simpan hari ke-0 didapatkan nilai TBA yang terkecil yaitu sebesar 3,547 mg malonaldehid/kg minyak dan untuk masa simpan hari ke-5 
Tabel 3. Hasil pengujian PV (mEq/kg) pada minyak ikan tongkol dengan perbedaan konsentrasi ekstrak lamun $C$. rotundata

\begin{tabular}{ccccc}
\hline \multirow{2}{*}{$\begin{array}{c}\text { Lama } \\
\text { penyimpanan } \\
\text { (hari) }\end{array}$} & A0 & A1 & A2 & A3 \\
\cline { 2 - 5 } & $0,05 \pm 0,02^{\mathrm{a}}$ & $18,36 \pm 0,58^{\mathrm{b}}$ & $32,05 \pm 1,00^{\mathrm{c}}$ & $46,74 \pm 0,58^{\mathrm{d}}$ \\
T0 & $12,35 \pm 0,58^{\mathrm{e}}$ & $22,03 \pm 1,00^{\mathrm{f}}$ & $35,39 \pm 0,58^{\mathrm{g}}$ & $29,71 \pm 1,53^{\mathrm{h}}$ \\
T5 & & & &
\end{tabular}

Keterangan:

Data merupakan hasil rata-rata dari tiga kali ulangan \pm standar deviasi.

Data yang diikuti dengan superscript yang berbeda menunjukkan perbedaan yang nyata $(p<5 \%)$

mengalami penurunan menjadi $3,310 \mathrm{mg}$ malonaldehid/ $\mathrm{kg}$ minyak. Hal ini dimungkinkan peroksida yang terbentuk masih kecil jumlahnya sebagai akibat dari reaksi senyawa aktif yang ada pada $C$. rotundata, sehingga untuk diubah menjadi malonaldehid juga terbatas dan menyebabkan jumlah kadar TBA menurun. Hal yang sama ditunjukkan oleh penelitian Ariyani dkk. (2012) yang menggunakan sampel ikan jambal patin kontrol yang mulai mengalami ketengikan pada penyimpanan minggu ke-4, sedangkan jambal patin dengan perlakuan penambahan ekstrak daun jambu pada 6 dan $12 \%$ belum mengalami ketengikan sampai akhir penyimpanan ( 8 minggu).

Penurunan angka TBA yang terjadi pada patin asin kontrol setelah 4 minggu penyimpanan, bukan berarti bahwa produk tidak tengik atau tidak teroksidasi, tetapi hal ini kemungkinan disebabkan oleh adanya reaksi antara malonaldehid hasil oksidasi dengan gugus amino pada daging yang membentuk struktur 1-amino-3-aminopropene. Rorong dkk. (2008) menyatakan bahwa oksidasi lemak dimulai dengan terbentuknya peroksida dan hidroperoksida. Tahap sesudahnya yaitu terurainya asam lemak dan perubahan hidroperoksida menjadi keton dan aldehid. Perubahan TBA selama waktu penyimpanan tidak stabil, hal ini diduga bahwa malonaldehid bersifat sangat labil dan sangat reaktif terhadap protein dan asam amino karena malonaldehid merupakan dekomposisi hidropeksida. Yuaniva dkk. (2011) melaporkan bahwa malonaldehid hasil oksidasi lemak bersifat labil dan sangat reaktif terhadap protein dan asam amino sehingga sulit digunakan sebagai parameter tingkat oksidasi dan hanya digunakan sebagai indicator penurunan kualitas asam lemak. Fenomena tersebut juga terdapat pada penelitian Oduor-Odote dan Obiero (2009), pada pengasapan ikan Mullet (Valamugil seheli) yaitu angka TBA ikan $V$. seheli asap 3,96 $\pm 0,12 \mathrm{mg}$ MDA/kg pada hari ke-4, turun menjadi 3,74 $\pm 0,03 \mathrm{mg}$ MDA/ $\mathrm{kg}$ pada hari ke- 8 kemudian turun lagi menjadi $0,12 \pm 0,04$ mg MDA/kg sesudah 19 hari penyimpanan. HHarikedua (2012) menambahkan bahwa reaksi asam lemak tidak jenuh
Tabel 4. Hasil pengujian TBA (malonaldehid/g) pada minyak ikan tongkol dengan perbedaan konsentrasi ekstrak lamun $C$. rotundata

\begin{tabular}{ccccc}
\hline \multirow{2}{*}{$\begin{array}{c}\text { Lama } \\
\text { penyimpanan } \\
\text { (hari) }\end{array}$} & A0 & A1 & A2 & A3 \\
\cline { 2 - 5 } & & & & \\
\hline T0 & $7,26 \pm 0,16^{\mathrm{e}}$ & $5,58 \pm 0,43^{\mathrm{c}}$ & $8,20 \pm 0,68^{\mathrm{f}}$ & $3,54 \pm 0,35^{\mathrm{b}}$ \\
T5 & $7,15 \pm 0,07^{\mathrm{e}}$ & $5,67 \pm 0,15^{\mathrm{c}}$ & $8,73 \pm 0,09^{\mathrm{f}}$ & $3,31 \pm 0,19^{\mathrm{a}}$ \\
\hline
\end{tabular}

Keterangan:

Data merupakan hasil rata-rata dari tiga kali ulangan \pm standar deviasi.

Data yang diikuti dengan superscript yang berbeda menunjukkan perbedaan yang nyata $(p<5 \%)$

berantai panjang dengan oksigen menghasil peroksida dan pada reaksi selanjutnya akan membentuk malonaldehid yang bersifat toksik.

\section{KESIMPULAN}

Lamun Cymodocea rotundata memiliki senyawa flavonoid dan fenolik yang bersifat antioksidan tetapi tidak mampu menghambat kerusakan oksidasi lemak atau minyak pada sampel minyak ikan tongkol. Semakin tinggi penambahan konsentrasi lamun C. rotundata dan semakin lama penyimpanan akan mengakibatkan kenaikan FFA, PV dan TBA.

\section{DAFTAR PUSTAKA}

Aminah, S. (2010). Bilangan peroksida minyak goreng curah dan sifat organoleptik tempe pada pengulangan penggorengan. Jurnal Pangan dan Gizi 01(01): 7-14.

Ariyani, F., Jovita, T.M., Gunaan dan Irma (2012). Pemanfaatan ekstrak air daun jambu biji sebagai antioksidan alami pada pengolahan patin asin. $J P B$ Perikanan 7(1): 49-60.

Berge, J.P. dan Barnathan (2005). Fatty acid from lipids of marine organism molecular biodiversity, roles as biomarkers, biologicaly active compound and economic aspect. Advances in Biochemical Engineering/ Biotechnology 96: 49-125.

Bougatef, A., Naima, N., Laila M., Rozenn R., Ahmed B., Didier G. dan Moncef, N. (2010). Purification and identification of novel antioxidant peptides from enzymatic hydrolysates of sardinelle (Sardinella aurita) by-products protein. Food Chemistry 118: 559-565.

Farvin, S., Grejsen, H.D. dan Jacobsen, C. (2012). Potato peel extract as a natural antioxidant in chilled storage of 
minced horse mackerel (Trachurus trachurus): effect on lipid and protein oxidation. Food Chemistry 131: 843851.

Harikedua, S.D. (2012). Efek penambahan ekstrak air jahe (Zingiber officinale Roscoe) dan penyimpanan dingin terhadap mutu sensori ikan tuna (Thunnus albacores). Jurnal Perikanan dan Kelautan Tropis 6(1): 36-40.

Jacoeb A.M., Sri, P. dan Rinto (2011). Anatomi, komponen bioaktif dan aktivitas antioksidan daun mangrove api-api (Avicena marina). Jurnal Pengolahan Hasil Perikanan Indonesia 14(2): 143-152.

Kesraoui, O., Mohamed, N.M., Thierry, M. dan Ferid, L. (2011). In vitro evaluation of antioxidant activities of free and bound phenolic compounds from Posidonia oceanica (1.) delile leaves. African Journal of Biotechnology 10(16): 3176-3185.

Khotimah, K., Darius dan Sasmito, B.B. (2013). Uji aktivitas senyawa aktif alga coklat (Sargassum fillipendulla) sebagai antioksidan pada minyak ikan lemuru (Sardinella longiceps). THPi Student Journal I(1): 1020.

Malangngi, L., Meiske, S. dan Jessy, P. (2012). Penentuan kandungan tanin dan uji aktivitas antioksidan ekstrak biji buah alpukat (Persea americana Mill.). Jurnal MIPA Unsrat Online 1(1): 5-10.

Oduor-Odote, P.M. dan Obiero, M. (2009). Lipid oxidation and organoleptic response during shelf storage of some smoked marine fish in Kenya. African Journal of Food Agriculture Nutrition and Development 9(3): 887-900.

Panagan, A. (2012). Analisis kualitatif dan kuantitatif asam lemak tak jenuh omega-3 dari minyak ikan patin (Pangasius pangasius) dengan metode kromatografi gas. Jurnal Penelitian Sains 15: 3.
Prabowo, A., Siti A.B. dan Amir, H. (2013). Ekstrak Sargassum sp. sebagai antioksidan dalam sistem emulsi minyak ikan selama penyimpanan pada suhu kamar. JPB Perikanan 8(1): 143-150.

Pradheeba, M., Dilipan, E., Nobi, E.P., Thangaradjou, T. dan Sivakumar, K. (2011). Evaluation of seagrass for their nutritional value. Indian Journal of Geo Marine Science 40(1): 105-111.

Rorong J., Henry, A. dan Ferdinan, P.R. (2008). Sintesis metil ester asam lemak dari minyak kelapa hasil pemanasan. Chemistry Progress 1(1): 9-18.

Soebagio, B., Taofik, R. dan Khairudin (2007). Pembuatan gel dengan aqupec hv-505 dari ekstrak umbi bawang merah (Allium cepa L.) sebagai antioksidan. Seminar Penelitian Dosen di Fakultas Farmasi Univesitas Padjadjaran, dalam Rangka Pengembangan Bidang Ilmu.

Ulfa, F., Apri, D.A. dan Romadhon (2014). Uji potensi aktivitas antioksidan dengan metode ekstrasi bertingkat pada lamun dugong (Thalassia hemprichii) di perairan jepara. Jurnal Pengolahan dan Bioteknologi Hasil Perikanan 3(3): 32-39.

Winarsi, H. (2007). Antioksidan Alami dan Radikal Bebas. Kanisius, Yogyakarta..

Yuaniva, N., Dewi, E.N. dan Ibrahim, R. (2011). Kemunduran mutu abon ikan nila merah (Oreochromis niloticus Trewavas) yang diproses secara deep frying selama penyimpanan suhu kamar. Jurnal Saintek Perikanan 6(1): 6-12. 